\title{
Multi-Physics Applications of Carbon Fiber Composite Materials: A Summary Review
}

\author{
Mohammad Faisal Haider* and Farzana Yasmeen \\ Department of Mechanical Engineering, USA \\ *Corresponding author: Mohammad Faisal Haider, Department of Mechanical Engineering, Columbia, SC 29208, USA
}

Submission: 㭰 January 08, 2018; Published: 眥 February 21, 2018

\begin{abstract}
Electrical properties such as electrical conductivity of composites play an essential role in aerospace structure and electronic applications. In such cases, composites materials need to sustain under electrical loads in addition to mechanical loads. It is important to understand reliability and multifunctional performance (coupled structural-thermal-electrical) of composite materials under electrical effect in different applications. Under electrical load, electrical effects are often coupled with structural integrity and thermal behavior due to "Joule heating" in composite parts and their joints. This multi-physical action leads to damage growth and ultimately affect the electrical and mechanical response.
\end{abstract}

\section{Introduction}

Multifunctional composites are used in today's aerospace, automotive and other structural applications. Composites are heterogeneous materials with anisotropic properties that can be tailored for a desired application. Such advanced "engineered materials" have the potential to evolve in even more complex heterogeneous formulations to meet the needs of the 21st century. Carbon fiber reinforced polymer (CFRP) has historically provided outstanding mechanical properties in a light weight design, led to many technological revolutions, and has recently attracted renewed interest because of its incorporation in the primary structures of major commercial aircraft. Boeing has built its next generation passenger airplane (787 Dreamliner) using CFRP at approximately halfthematerial weight[1].Additionally to their excellentmechanical properties, CFRPs are also electrically conductive materials. Carbon fibers are excellent electrically conductive reinforcing materials for transforming electrically non-conductive polymers to conductive materials, which have shown ideal for a variety of applications. Particular examples of the aforementioned use of CFRPs in various applications are the following: electromagnetic interference (EMI) shielding, photovoltaic devices, fuel cell, transparent conductive coatings, structural heating elements, satellite, inflatable space structures, antennas, electromagnetic field wave guide, transducers etc [2-8].

\section{Recent Developments}

Composites with anisotropic electrical properties need to be engineered for multi-functional performance (coupled structuralthermal-electrical) under electrical effect. Under electrical load, electrical effects are often coupled with structural integrity and thermal behavior due to "Joule heating" in composites and their joints. This multi-physical action leads to damage growth and ultimately affect the electrical response. It is important to understand how multi-physics properties depend on evolution of damage. Fazzino et al. [9] used impedance spectroscopy for progressive damage analysis in woven composites. Electric potential or electrical resistance method can also be used to detect damage and delamination in composites [10-11], Wang et al. [12] demonstrated self-sensing damage detection by electrical resistance measurement of composite materials. However, the prior work has focused only on damage detection. Multi-physics response of degraded composite and evolution of damage due to electrical currents is still not fully understood. The electrical properties of the system (i.e. its conductivity and dielectric permittivity) are influenced by the properties of the constituents, interaction between them and geometrical configuration [13-19]. Damage tolerance in relation to lightning strikes is now an important engineering problem related to composite aircraft structures [2023]. There are two types of effect can be observed due to lightning strike on an aircraft: direct effect and indirect effect [24-26]. When a lightning strike occurs, large amplitude current is injected at the point of injection. This is known as direct effect. At the point of injection local electrical, mechanical and thermal effect can be observed. But in indirect effect, low density current circulates over all electrically conducting parts of the composite structure. The impulse current waveform of lightning strike is described in MIL and SAE standard [27]. Electrical current of continuing component in lightning strike is much lower in amplitude (200-800A) but stays for longer duration. This can cause indirect effects due to field coupling and high induced voltages. Electric current may 
divert to a concentrate path where conductivity is higher than the surroundings and produce excessive heating. This induced current can lead to significant damage in composite structure (Figure 1). Two major types of matrix damages are commonly observed in unidirectional composites $[18,19]$. One form of matrix damage is due to Joule heating during on axis electrical loading. As fibers are good conductors and can sustain heat generated due to conduction. Most of the damages can be seen in the matrix due to heat generation by Joule effect. Due to Joule heating matrix decomposes around the fiber and causes more fiber contacts with each other which results in decreasing of electrical impedance (Figure 1). Debonding at the fiber-matrix interface is common damage phenomena due to decompose of matrix. This can easily explain by thermal-electrical coupling behavior. Another damage form is matrix crack due to electron hopping between two consecutive carbon fibers in a single ply as shown in Figure 1. During passing current in on axisdirection, current can also flow in off axis direction but different in amount due to anisotropy behavior of composite [28]. In off axis direction there is no direct conduction path, which leads electron hopping from one fiber to another fiber. During this process, it creates matrix crack between two fibers. Another possible reason for matrix crack is magnetic force or Lorentz force (Figure 2).

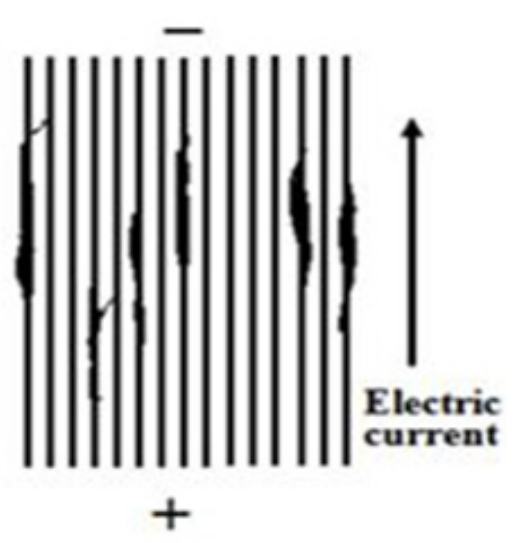

Figure 1: Matrix decomposition along the fiber direction and matrix crack between fibers.

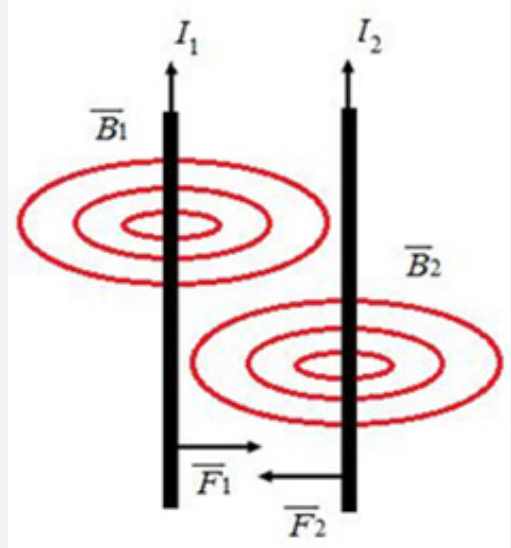

Figure 2: Forces between two fibers due to current or moving charges.
Local current density in those areas could be higher than the bulk current density. Larger potential difference may also observe during this process, thereby resulting electrical breakdown between fiber to fiber or in between lamina. The direct and indirect effect of electric current has been studied so far by many researchers [2931]. Therefore, a coupled thermal-electrical analysis of carbon fiber reinforced polymer composites (CFRP) exposed to electrical current is under recent research in order to elucidate the damage behavior caused by current. Coupled electrical thermal effect on composite is reported by several researchers [32-35]. Current research may help to understand coupled structural-thermal-electrical behavior in composite similar to indirect effect of lightning strike [13-19,36]. However, findings from this research do not necessarily applicable only to aircraft lightning protection but also relevant in other electrical applications such as, electromagnetic interference (EMI) shielding, photovoltaic devices, fuel cell, transparent conductive coatings, structural heating elements, satellite, space shuttle, antennas etc.

\section{Conclusion}

Electrical effects are often coupled with the structural integrity and the thermal behavior due to "Joule heating" in the composite parts and in their joints. Thermal-electrical properties also depend on progressive increase in current intensity and damage state. Electrical current can cause significant damage in the dielectric matrix material while conducting through the fibers. Thus ultimately causes significant change in the electrical and mechanical properties due to material state changes. The material state depends heavily on coupled thermal-electrical effect and when the electrical distribution.

\section{References}

1. Miller A (2007) The Boeing 787 dreamliner. Keynote address. In: $22^{\text {nd }}$ American society for composites technical conference, Seattle, Western Australia.

2. Chen YC, Raravikar NR, Schadler LS, Ajayan PM, Zhao YP, et al. (2002) Ultrafast optical switching properties of single-wall carbon nanotube polymer composites at $1.55 \mu \mathrm{m}$. Applied Physics Letters 81(6): 975-977.

3. Kim HM, Kim K, Lee CY, Joo J, Cho SJ, et al. (2004) Electrical conductivity and electromagnetic interference shielding of multiwalled carbon nanotube composites containing Fe catalyst. Applied Physics Letters 84(4): 589-591.

4. Ramasubramaniam R, Chen J, Liu H (2003) Homogeneous carbon nanotube/polymer composites for electrical applications. Applied Physics Letters 83(14): 2928-2930.

5. Raihan, Rassel, Adkins JM, Baker J, Rabbi F, et al. (2014) Relationship of dielectric property change to composite material state degradation. Composites Science and Technology 105: 160-165.

6. Chung DDL (2001) Electromagnetic interference shielding effectiveness of carbon materials. Carbon 39(2): 279-285.

7. Wolf H, Willert-Porada M (2006) Electrically conductive LCP-carbon composite with low carbon content for bipolar plate application in polymer electrolyte membrane fuel cell. Journal of Power Sources 153(1): 41-46.

8. Piascik B, Vickers J, Lowry D, Scotti S, Stewart J, et al. (2012) Space technology roadmaps (TA12): materials, structures, mechanical systems and manufacturing in space technology roadmaps. NASA, USA. 
9. Fazzino PD, Reifsnider KL, Majumdar P (2009) Impedance spectroscopy for progressive damage analysis in woven composites. Composites Science and Technology 69(11-12): 2008-2014.

10. Akira T, Matsuura K (1995) Application of electric potential method to smart composite structures for detecting delamination. In Proceedings of the Tenth International Conference on Composite Materials: Structures Woodhead Publishing, UK 5: p.323. carbon fibre composite materials using an electrical potential technique. Smart materials and structures 7(4): 456.

12. Wang S, Chung DDL (2006) Self-sensing of flexural strain and damage in carbon fiber polymer-matrix composite by electrical resistance measurement. Carbon 44(13): 2739-2751. microstructural changes of composite materials. ICOLSE, Seattle, Washington, USA.

14. Haider MF, Majumdar PK, Reifsnider KL (2013) Study of damage in carbon fiber reinforced composites due to electric current. American Society for Composites $28^{\text {th }}$ Technical Conference, Pennsylvania, USA.

15. Majumdar PK, Haider MF, Reifsnider KL (2013) Effect of fiber orientation on AC conductivity of composite materials. SAMPE, California, USA.

16. Majumdar PK, Reifsnider KL, Raihan Md, Haider MF (2013) Study of damage evolution in composite materials using 3D X-ray Microscope. SAMPE, California, USA.

17. Majumdar PK, Haider MF, Reifsnider KL (2013) Multi-physics response of structural composites and framework for modeling using material geometry. $54^{\text {th }}$ AIAA/ASME/ASCE/ASC structures, structural Dynamics, and Materials conference, Boston, Massachusetts, USA.

18. Haider MF, Majumdar PK, Angeloni S, Reifsnider KL (2015) Measurement and prediction of electrical response of composite materials. SAMPE Baltimore, Maryland, USA.

19. Haider MF, Majumdar PK, Angeloni S (2015) Degradation of carbon fiber composite materials due to electrical current and potential impact on synergistic durability. American Society for Composites $30^{\text {th }}$ Technical Conference, Michigan State University, East Lansing, Michigan, USA.

20. Haider MF (2016) Anisotropic electrical response of carbon fiber reinforced composite materials, Doctoral dissertation, University of South Carolina, USA.

21. Feraboli P, Miller M (2010) Damage resistance and tolerance of carbon/ epoxy composite coupons subjected to simulated lightning strike. Composites: Part A 40: 954-967.
11. Irving PE, Thiagarajan C (1998) Fatigue damage characterization in

13. Majumdar PK, Haider MF, Reifsnider KL (2013) AC Conductivity and

22. Gou J, Tang Y, Liang F, Zhao Z, Firsich D, et al. (2010) Carbon nanofiber paper for lightning strike protection of composite materials. Composites Part B: Engineering 41(2): 192-198.

23. Mall S, Ouper BL (2009) Compression strength degradation of nanocomposites after lightning strike. Journal of Composite Materials $43(24)$.

24. Goodloe CC (1999) Lightning protection guidelines for aerospace vehicles. NASA, Alabama, USA.

25. Fisher FA, Plumer JA, Perala RA (1989) Aircraft lightning protection handbook. Lightning technologies inc pittsfield ma.

26. Gagné M, Therriault D (2014) Lightning strike protection of composites. Progress in Aerospace Sciences 64: 1-16.

27. MIL-STD-1757A (1983) Lightning qualification test techniques for aerospace vehicles and hardware, MIL, Department of Defense.

28. Haider MF, Majumdar PK, Angeloni S, Reifsnider KL (2017) Nonlinear anisotropic electrical response of carbon fiber-reinforced polymer composites. Journal of Composite Materials.

29. Plumer JA, Robb JD (1982) The direct effects of lightning on aircraft. IEEE Transactions on Electromagnetic Compatibility 2: 158-172.

30. Punekar GS, Kandasamy C (2011) Indirect effects of lightning discharges. Serbian Journal of Electrical Engineering 8(3): 245-262.

31. Parmantier JP, Issac F, Gobin V (2012) Indirect Effects of Lightning on Aircraft and Rotorcraft. AerospaceLab (5): pp. 1.

32. Dong Q, Guo Y, Sun X, Jia Y (2015) Coupled electrical-thermal-pyrolytic analysis of carbon fiber/epoxy composites subjected to lightning strike. Polymer 56: 385-394.

33. Abdelal G, Murphy A (2014) Nonlinear numerical modelling of lightning strike effect on composite panels with temperature dependent material properties. Composite Structures 109: 268-278.

34.Zhupanska OI, Sierakowski RL (2011) Electro-thermo-mechanical coupling in carbon fiber polymer matrix composites. Acta mechanica 218(3-4): 319-332.

35. Ogasawara T, Hirano Y, Yoshimura A (2010) Coupled thermal-electrical analysis for carbon fiber/epoxy composites exposed to simulated lightning current. Composites: Part A 41: p. 973-981.

36. Haider MF, Haider MM, Yasmeen F (2016) Micromechanics model for predicting anisotropic electrical conductivity of carbon fiber composite materials. In AIP Conference Proceedings 1754(1): p. 030011.

Creative Commons Attribution 4.0

International License

For possible submissions Click Here

\section{Your subsequent submission with Crimson Publishers will attain the below benefits}

- High-level peer review and editorial services

- Freely accessible online immediately upon publication

- Authors retain the copyright to their work

- Licensing it under a Creative Commons license

- Visibility through different online platforms

- Global attainment for your research

- Article availability in different formats (Pdf, E-pub, Full Text)

- Endless customer service

- Reasonable Membership services

- Reprints availability upon request

- One step article tracking system 